\title{
Tumor de Pindborg (tumor odontogénico epitelial calcificante)
}

\author{
Pindborg tumor (Calcifying epithelial odontogenic tumor)
}

\author{
J. Rubio Palau', C. Bescós Atín², J. Pamias Romero², M. Sáez Barba², G. Raspall Martín, \\ P. Huguet Redecilla ${ }^{4}$
}

Resumen: El objetivo del presente artículo es realizar una revisión de la literatura del tumor de Pindborg a propósito de un caso. El interés radica en su baja frecuencia y a la importancia de la anatomía patológica para su diagnóstico y correcto tratamiento ya que puede confundirse en algunos casos con otras tumoraciones benignas, a diferencia de las cuales, en este tumor debe realizarse una resección con márgenes de seguridad para disminuir la probabilidad de recidiva.

Palabras clave: Tumor de Pindborg; Tumor odontogénico epitelial calcificante.

Recibido: 19.09 .06

Aceptado: 18.12 .06

\begin{abstract}
The aim of this article is to review the literature on Pindborg tumor based on a case. In view of its low frequency and the importance of histology for its correct diagnosis and treatment as it can be confused with other benign tumors, appropriate resection is necessary with tumor-free margins in order to reduce the probability of local recurrence.
\end{abstract}

Key words: Pindborg tumor; Calcifying epithelial odontogenic tumor.

\footnotetext{
1 Médico Residente.

2 Médico Adjunto.

3 Jefe de Servicio. Servicio de Cirugía Oral y Maxilofacial.

4 Médico Adjunto. Servicio de Anatomía Patológica.

Servicio de Cirugía Oral y Maxilofacial.

Hospital Universitari Vall d'Hebron. Barcelona, España.
}

\section{Correspondencia:}

Josep Rubio Palau

Paseo Vall d'Hebron, 119-129

08035 Barcelona, España

Email: jrubiopalau@yahoo.es 


\section{Introducción}

El tumor de Pindborg o también llamado tumor odontogénico epitelial calcificante (TOEC) es una neoplasia benigna pero con carácter invasivo local y tendencia a la recidiva, de baja frecuencia y que suele asentar en la mandíbula.

EI TOEC es una neoplasia rara que representa entre 0,17 y $1,8 \%$ de todos los tumores odontogénicos ${ }^{1}$ y de la que tan sólo se han publicado unos 200 casos, con una media de 4 casos nuevos por año en el mundo. ${ }^{2}$

Se han descritro dos variantes según su localización: intraósea o central (94\% de los casos) y extraósea, periférica o de tejidos blandos ( $6 \%$ de los casos). ${ }^{2}$ Actualmente no hay consenso acerca del origen del tumor y se cree que deriva de elementos epiteliales del órgano del esmalte, aunque otros autores creen que deriva de remanentes celulares de la lámina basal o a partir del estrato basal del epitelio gingival. ${ }^{3}$

La afectación mandibular es en frecuencia el doble de la maxilar y suele asentar a nivel premolar-molar, ${ }^{4}$ aunque se ha descrito una predilección en el maxilar en asiáticos. ${ }^{1}$ Frecuentemente se asocia a dientes no erupcionados, especialmente molares mandibulares (52\%) y quistes odontógenos.4,5 También se ha descrito la afectación bimaxilar y la afectación bilateral. ${ }^{3}$

No hay una predilección de sexo en la variante central y más de dos tercios de las lesiones aparecen entre la tercera y quinta décadas de la vida, ${ }^{2}$ con una media de edad de 40,3 años en el central y 31,8 en el periférico. ${ }^{4}$

\section{Caso clínico}

El paciente es un varón de 38 años que acudió al Servicio de Cirugía Oral y Maxilofacial del Hospital Universitari Vall d'Hebron, remitido de otro centro, por tumoración mandibular de 1 año de evolución (Fig. 1).

Como antecedentes patológicos destaca el ser exadicto a drogas por vía parenteral, ser VHC positivo y VIH positivo en tratamiento con antiretrovirales. A la exploración se apreciaba una tumoración mandibular derecha de aproximadamente $5 \mathrm{cms}$ de tamaño, fija y de consistencia dura manteniéndose la integridad de la mucosa oral. En la ortopantomografía aparecía una lesión mixta

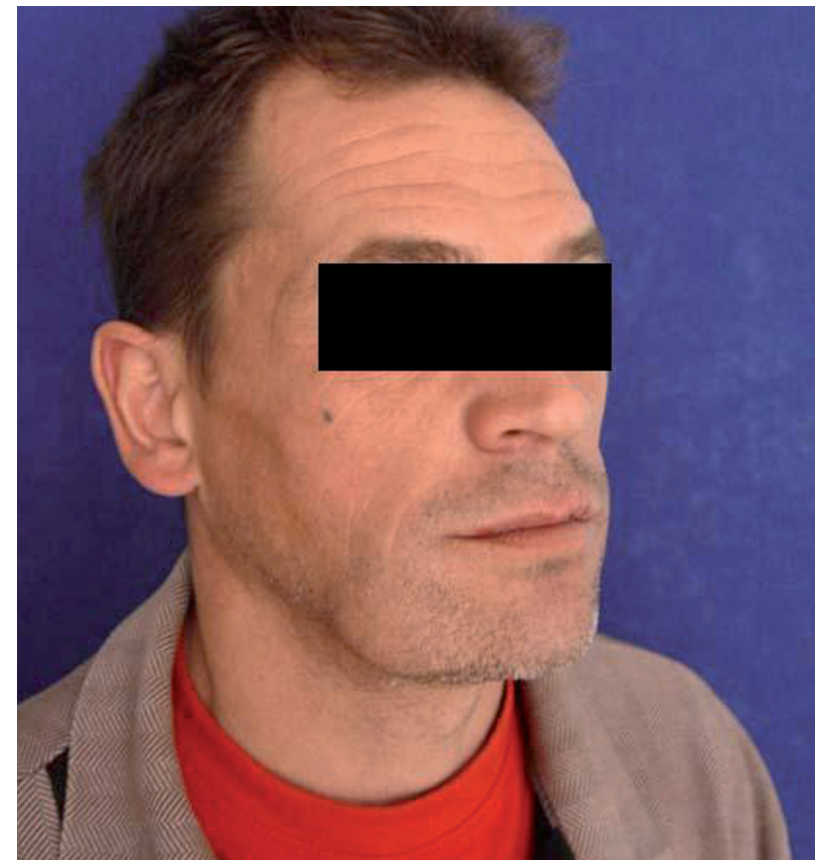

Figura 1. Fotografía de tres cuartos antes de la intervención quirúrgica.

Figure 1. Three-quarter view before surgery.

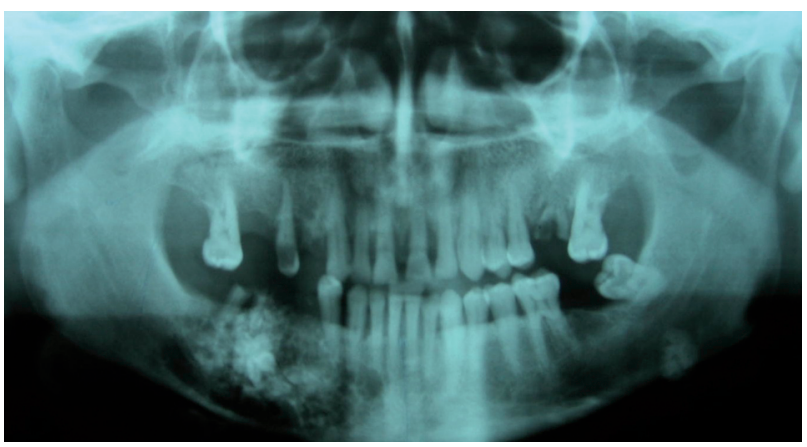

Figura 2. Ortopantomografía antes de la intervención quirúrgica. Figure 2. Orthopantomography before surgery.

\section{Introduction}

Pindborg tumor, also called Calcifying Epithelial Odontogenic Tumor (CEOT) is an uncommon, benign neoplasm with an invasive local nature. It tends to arise in the mandible and to recur. CEOT is a rare neoplasm that represents between 0.17 and $1.8 \%$ of all odontogenic tumors, ${ }^{1}$ and only 200 cases have been published, with an average of 4 new cases per year in the world. ${ }^{2}$

Two varieties have been described according to their location: intraosseous or central (94\% of cases) and extraosseous, peripheral or of soft tissues (6\% of cases). ${ }^{2}$ There is currently no consensus as to the origins of the tumor, and it is believed that it is derived from epithelial elements of the enamel organ, although other authors believe that it is derived from cellular remains of the basal lamina or from the basal layer of gingival epithelium. ${ }^{3}$

Mandibular involvement is commonly twice that of the maxilla, and it tends to arise in the premolar-molar area although a predilection has been described for the maxil-

la in orientals. It is commonly associated with unerupted teeth, especially mandibular molars (52\%) and odontogenic cysts. 4,5 Bimaxillary and bilateral involvement has also been described. ${ }^{3}$

There is no sex predilection in the central variety and more than two thirds of the lesions appear between the third and fifth decades in life. ${ }^{2}$ The mean age is 40.3 years for central tumors and 31.8 for peripheral ones. ${ }^{4}$

\section{Case Report}

The patient was a 38 year old male that attended the Department of Oral and Maxillofacial Surgery of the Hospital Universitari Vall d'Hebron, having been referred by 
con calcificaciones en su interior que afectaba la hemimandíbula derecha (Fig. 2).

En la TC se observaba una lesión mixta expansiva en cuerpo de mandíbula derecha que destruía las corticales

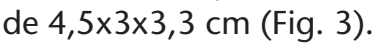

La biopsia realizada informaba de tumor odontogénico epitelial calcificante.

El paciente fue sometido a una hemimandibulectomía derecha con reconstrucción microquirúrgica con peroné (Figs. 4 y 5 ).

La anatomía patológica reveló una masa de $4 \times 2,5 \mathrm{~cm}$ de superficie irregular con aspecto heterogéneo, áreas congestivas y restos de piezas dentarias, que confirmó el diagnóstico de tumor odontogénico epitelial calcificante de mandíbula y que infiltraba partes blandas periósticas. El nervio mentoniano no presentaba invasión y la biopsia intraoperatoria de ganglio de cadena facial izquierda no presentaba metástasis (Figs. 6 y 7 ).

La evolución postoperatoria fue favorable y fue dado de alta tolerando dieta y con control de las heridas en consultas externas (Figs. 8, 9 y 10).

\section{Discusión}

Clínicamente este tipo de tumores se caracterizan por ser asintomáticos en el momento del diagnóstico, aunque el lento crecimento del tumor puede producir efectos mecánicos y a pesar de que se trata de una neoplasia benigna, puede invadir localmente. ${ }^{3}$ El tumor crece por infiltración y puede producir una expansión de la cortical, movimiento dentario y resorción de las raíces. En algunos casos puede producir dolor, obstrucción nasal, epistaxis, cefalea e incluso sangrado. ${ }^{3} \mathrm{~A}$ nivel maxilar puede afectar a los senos. La tasa de recurrencia oscila entre $10 \mathrm{y}$ $14 \% .^{1,4}$

La variante extraósea suele localizarse en la encía anterior como una masa indolora parecida a un épulis, ${ }^{2}$ y sin afectación ósea del maxilar aunque el hueso adyacente suele mostrar una erosión superficial. Su comportamiento es menos agresivo que la variante central, lo que permite realizar un tratamiento más conservador. ${ }^{4}$

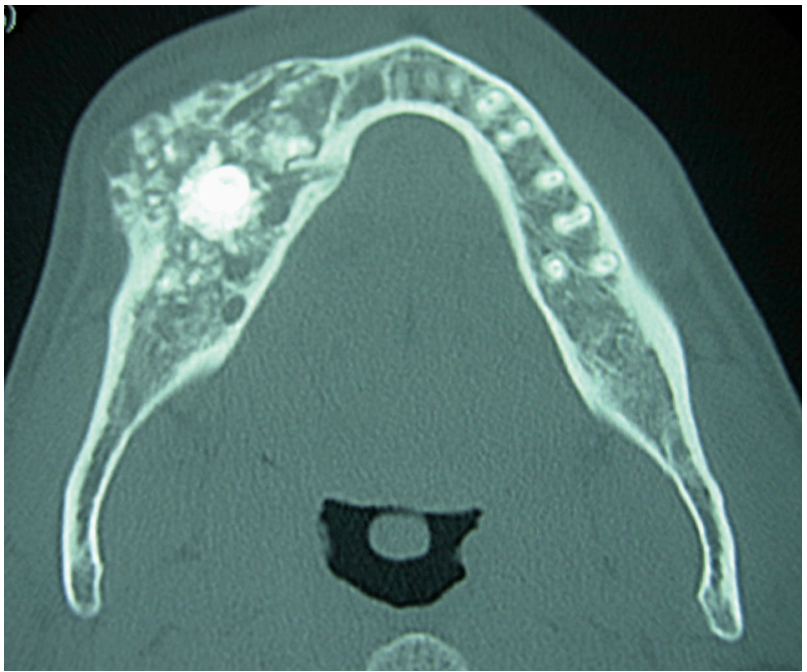

Figura 3. TC antes de la intervención quirúrgica. Figure 3. CT scan before surgery.

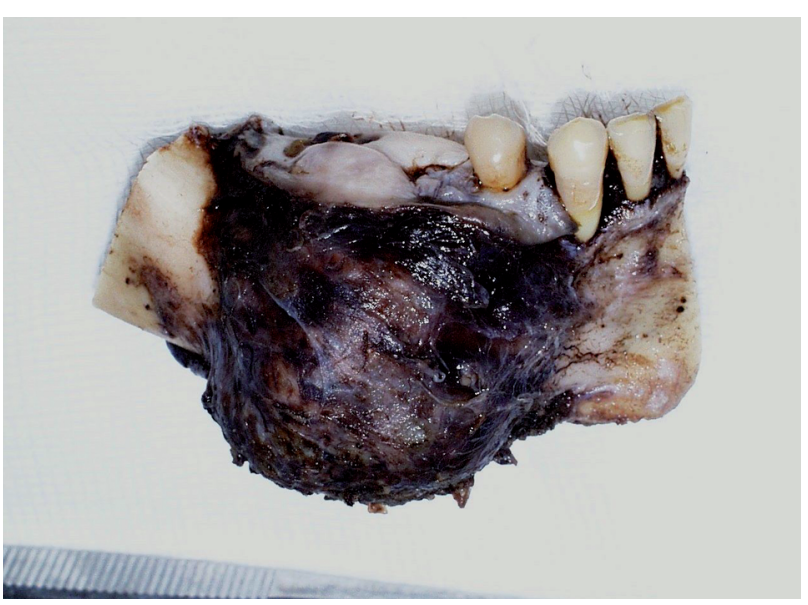

Figura 4. Fotografía macroscópica de la pieza de extirpación del tumor.

Figure 4. Macroscopic photograph of the resected tumor specimen.

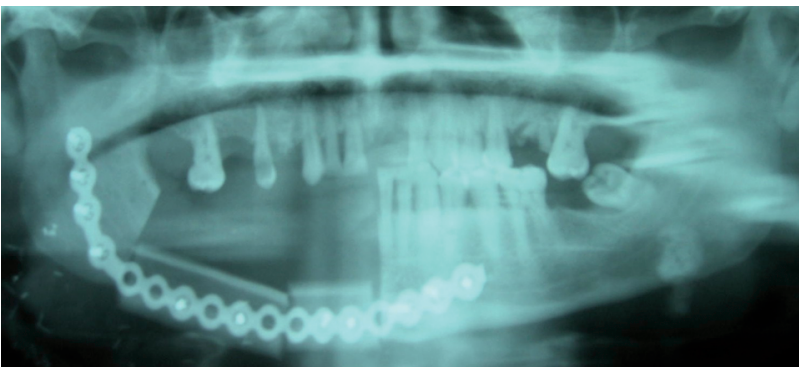

Figura 5. Ortopantomografía después de la intervención quirúrgica.

Figure 5. Orthopantomography after surgery. another center because of a tumor-like mass in the mandible that had been evolving for a year. (Fig. 1) His medical history included an ex-addiction to parenteral drug use. He was HCV and HIV positive and undergoing antiretroviral therapy. On examination a right-sided mandibular tumor-like mass could be appreciated that measured $5 \mathrm{cms}$, which was attached and hard in consistency. The oral mucosa was intact. The orthopantomography showed a mixed lesion with calcifications in its interior that was affecting the right side of the mandible. (Fig. 2) The CAT scan showed an expansive mixed lesion in the right mandibular body that was destroying cortical bone, which measured $4.5 \times 3 \times 3.3$ $\mathrm{cm}$. (Fig. 3) The biopsy carried out reported a calcifying epithelial odontogenic tumor. The patient underwent a mandibulectomy of the right half which was reconstructed microsurgically with fibula. (Figs. 4 y 5) The anatomic pathology report described a mass measuring $4 \times 2.5 \mathrm{~cm}$ with an irregular surface and $a$ heterogeneous appearance, congestive areas and remains of teeth. This confirmed the diagnosis of calcifying epithelial odontogenic tumor of the mandible that was infiltrating the soft tissue of the periosteum. The mental nerve showed no invasion, and the intraoperative biopsy of the left facial system lymph node showed no signs of metastasis (Figs. 6 y 7). The postoperative period was favorable and he was discharged able to tolerate food. His wounds were checked on an outpatient basis (Figs. 8,9 y 10). 
El diagnóstico suele producirse al realizar una radiografía rutinaria, por lo que debido a su potencial carácter invasivo local debe realizarse una TC para determinar la extensión y el tratamiento. ${ }^{3,4}$

A nivel radiológico el tumor pasa por distintas fases evolutivas. Inicialmente el tumor es radiolúcido como un quiste odontógeno (sobre todo cuando está en relación con un diente incluido) o un ameloblastoma quístico. A continuación sigue un patrón mixto aunque algunos tumores grandes pueden permanecer radiolúcidos, ${ }^{4} \mathrm{y}$ aparecen calcificaciones intralesionales. ${ }^{3}$ Finalmente aparece un patrón irregular, con áreas uni o multiloculares como un panal de abejas debido a la destrucción y calcificación tumoral.2,3 El tumor suele estar bien circunscrito radiológicamente a pesar que los márgenes escleróticos pueden no ser evidentes. $^{2}$

Los tumores periféricos suelen ser radiolúcidos aunque el hueso adyacente puede mostrar erosiones superficiales. ${ }^{4}$

La TC es útil para mostrar las calcificaciones, dientes no erupcionados y las erosiones óseas, ${ }^{1}$ y suele mostrar una lesión bien delimitada, que expande el hueso, con adelgazamiento de la cortical, multilocular, con septos óseos, radiopacidades y dientes incluidos, aunque en este caso aparecía una lesión de carácter infiltrante dado su avanzado estado evolutivo. La resonancia magnética muestra una lesión hiperintensa en T2 e hipointensa en T1, estas características distinguen al tumor de otras neoplasias más agresivas. ${ }^{4}$ Las ventajas de la RM son la ausencia de radiaciones ionizantes y una mayor definición de los tejidos blandos.

La histología es el aspecto más variable de este tumor. El criterio característico para diagnosticarlo son unas masas de grandes células epiteliales poligonales con bordes bien definidos y puentes intercelulares. ${ }^{2}$ El citoplasma es abundante y eosinofílico. A menudo hay pleomorfismo celular y los núcleos suelen ser prominentes y con una gran variabilidad de tamaño, forma y número. No suelen haber mitosis. A nivel extracelular suelen haber acumulaciones de material de tipo amiloide con birrefringencia de color verde manzana bajo luz polarizada después de ser teñida con rojo Congo. ${ }^{4}$ Un hallazgo muy importante es la calcificación concéntrica de este material amiliode formando los anillos de Liesegang, que son patognomónicos de este tumor. ${ }^{2}$ Este material amiloide calcificado produce un estímulo sobre el estroma tumoral que lo lleva a segregar una matriz de colágeno posteriormente calcificable. ${ }^{3}$

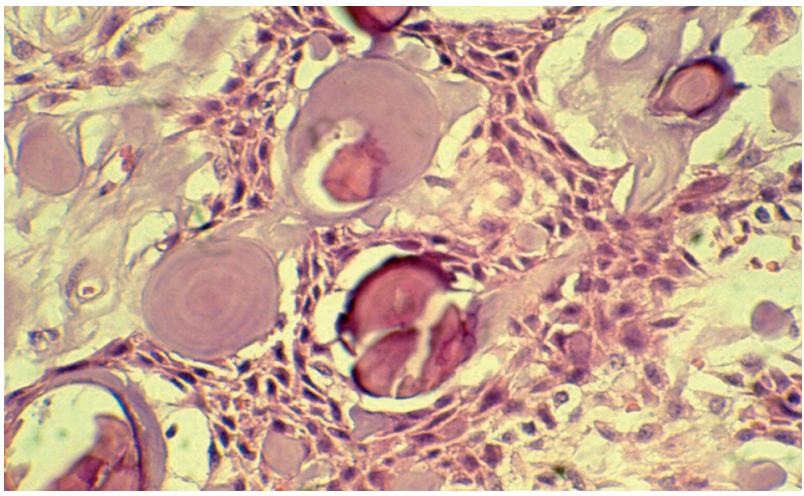

Figura 6. Fotografía histológica hematoxilina-eosina (250x): Células epiteliales regulares sin atipias y presencia de concreciones eosicificaciones.

Figure 6. Histological photograph with hematoxylin-eosin (250x) with eosinophilic deposits forming ring-like structures (Liesegang rings)

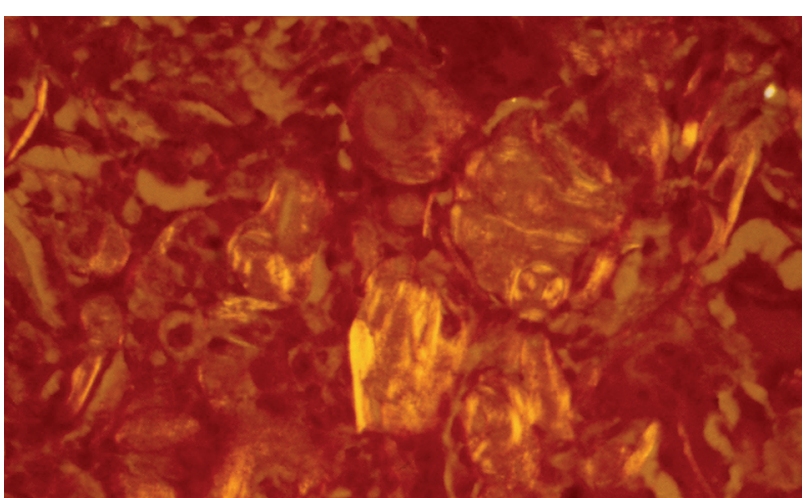

Figura 7. Tinción rojo Congo y examen con luz polarizada (250x): Se observa birrefringencia de color verde manzana de los anillos de Liesegang. Birefringence of an apple-green color can be observed in Liesegang's rings.

\section{Discussion}

Clinically these types of tumors are typically asymptomatic at diagnosis, and although they grow slowly, the tumor can have mechanical effects. In spite of being a benign neoplasm, it can be locally invasive. ${ }^{3}$ The tumor grows by means of infiltration and there can be expansion of the cortical bone, dental movement and root resorption. In some cases there may be pain, nasal obstruction, epistaxis, headaches and even bleeding. ${ }^{3}$ In the maxilla the sinuses may be affected. The recurrence rate is between 10 and $14 \% .1,4$

The extraosseous type tends to be located in the anterior gingiva presenting as a painless mass similar to an epulis. ${ }^{2}$ There is no involvement of the jaw although the adjacent bone tends to show superficial erosion. Its behavior is less aggressive than the central variety, which permits more conservative treatment. ${ }^{4}$

The diagnosis tends to arise after routine radiography and, given its potentially invasive nature, a CAT scan should be carried out in order to determine its extension and treatment. ${ }^{3,4}$

Radiologically the tumor has different stages of development. Initially the tumor is radiolucent, like an odontogenic cyst (especially when it is by an unerupted tooth) or like a cystic ameloblastoma. A mixed pattern will then follow, although some larger tumors may remain radiolucent4 and intralesional calcifications will appear. ${ }^{3}$ Finally, an irregular pattern will be displayed, with uni- or multilocular areas, like a honeycomb, due to destruction and tumor calcifications. ${ }^{2,3}$ The tumor tends to be well-circumscribed radiologically in spite of having sclerotic margins that may not be visible. ${ }^{2}$ The peripheral tumors tend to be radiolucent although the adjacent bone tends to have superficial erosion. ${ }^{4}$

The CAT scan is useful for showing calcification, unerupted teeth and bone erosion. ${ }^{1}$ It will reveal a well-defined multilocular lesion expanding the bone, together with thinning of 
Se han descrito distintas variantes de TOEC: de células claras (el cual suele tener un comportamiento más agresivo y tiene una tasa de recurrencia mayor), ${ }^{2}$ de células de Langerhans, de células mioepiteliales o formador de cemento.

Según la radiología debe realizarse el diagnóstico diferencial con el ameloblastoma, el mixoma, el quiste óseo aneurismático y los quistes odontógenos. ${ }^{4}$ También deben desacartarse el granuloma de células gigantes, el fibroma osificante-cementificante, el fibrodontoma ameloblástico y el fibroma ameloblástico. Si la lesión presenta un sangrado importante debe realizarse el diagnóstico diferencial con el angioma central mandibular. ${ }^{3}$ Si hay presencia de células claras se deben considerar el carcinoma odontógeno de células claras, el ameloblastoma de células claras, el carcinoma intraóseo, las neoplasias de glándulas salivares y el osteoblastoma agresivo. ${ }^{5}$

La base del tratamiento es la cirugía y ésta debe individualizarse en cada caso según la extensión, localización y características del paciente. Si se opta por un tratamiento conservador mediante enucleación o curetaje incluyendo un margen de tejido sano junto con un prolongado seguimiento, debe considerarse que la tasa de recidiva es del $15-30 \%$ a los 2-4 años.4 Por lo tanto, debido a su carácter infiltrativo, es preferible la resección con un $\mathrm{cm}$ de tejido sano clínica y radiológicamente $(0,5$ en los periféricos por su menor agresividad) consiguiendo así una ausencia de recidiva. En los casos en que afecte al maxilar o sea la variante de células claras debe tratarse de manera más agresiva. ${ }^{5}$ Consecuentemente la mejor forma de tratamiento es incluir unos márgenes de $1-1,5 \mathrm{~cm}$ junto con un seguimiento de 5-10 años. ${ }^{4}$

\section{Conclusiones}

El tumor de Pindborg es una lesión benigna de muy baja frecuencia pero que debido a su comportamiento impredecible y a su radiología inespecífica obliga a la realización de un estudio anatomopatológico y una cirugía resectiva para minimizar la probabilidad de recidiva, junto con un seguimiento postoperatorio de al menos cinco años.

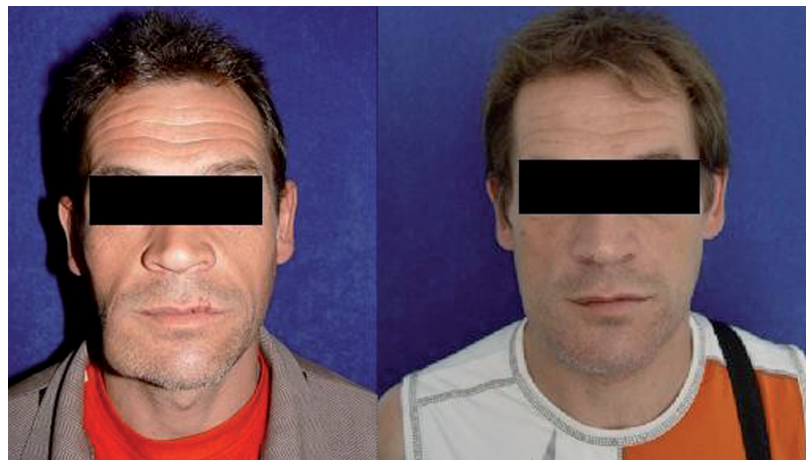

Figura 8. Fotografía de frente antes y después de la intervención quirúrgica.

Figure 8. Face-on photograph before and after surgery.

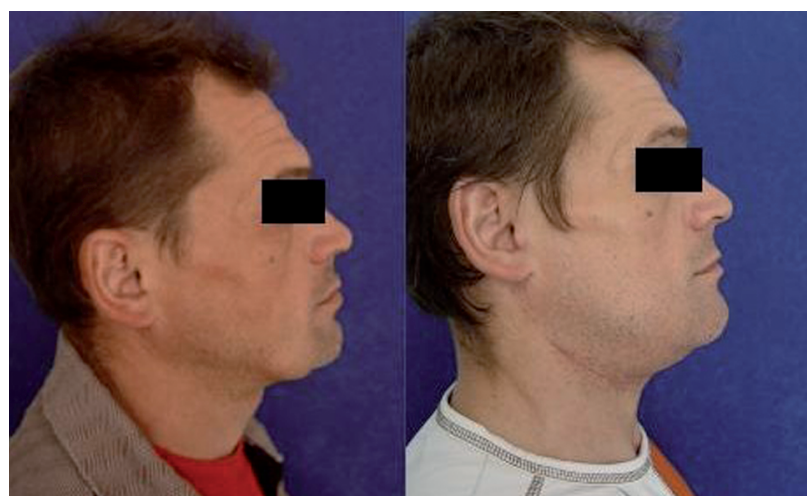

Figura 9. Fotografía de perfil antes y después de la intervención quirúrgica.

Figure 9. Photograph showing profile before and after surgery.

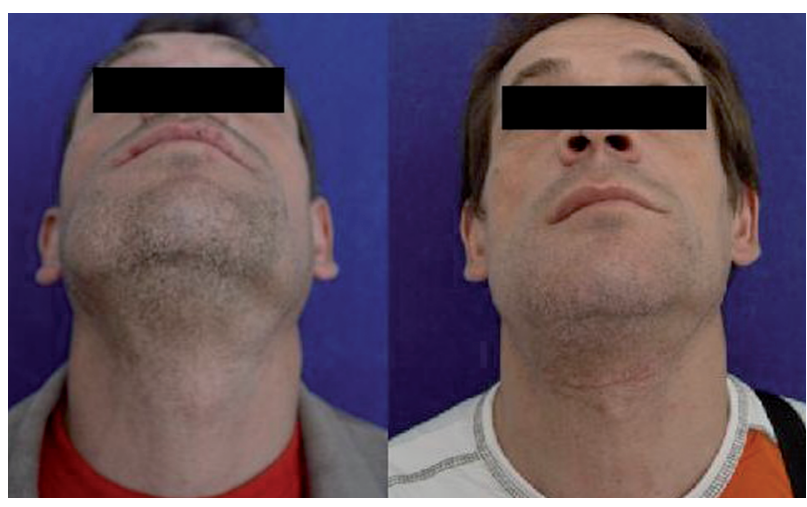

Figura 10. Fotografía basal antes y después de la intervención quirúrgica.

Figure 10. Bottom-up photograph before and after surgery. the cortical layer, bony septum, radio-opacity and unerupted teeth, although in this case an infiltrative type of lesion was shown given its advanced stage. Magnetic resonance will show a hyperintense lesion on $T 2$ weighted sequences and hypointense on T1. These characteristics distinguish the tumor from other neoplasms that are more aggressive. ${ }^{4} \mathrm{RMI}$ has the advantage of not using ionizing radiation and soft tissue is better defined.

The more changeable aspect of this tumor is its histology. The characteristic criteria for diagnosing it are large polygonal epithelial cells with welldefined borders and intercellular bridges. ${ }^{2}$ The cytoplasm is abundant and eosinophilic. There is often cellular pleomorphism and the nuclei tend to be prominent and with a great variety of sizes, shapes and numbers. Mitosis tends not to be seen. At an extracellular level there tends to be accumulation of an amyloid type of material with birefringence of an apple-green color under polarized light after Congo red staining. ${ }^{4} A$ very important finding is concentric calcification in the amyloid material that will form Liesegang rings, which are pathognomonic for this tumor. ${ }^{2}$ This calcified amyloid material stimulates the tumor stroma which leads it to segregate a collagenous matrix which will calcify. ${ }^{3}$

Different varieties of CEOT have been described: clear cell (which tends to be more aggressive and that has a greater recurrence rate), ${ }^{2}$ Langerhan's cell, myoepithelial cell or cementum-forming.

The differential diagnosis should include ameloblastoma, myxoma, aneurismatic bone cyst and odontogenic cysts, depending on the radiographs. ${ }^{4}$ Giant cell granuloma should also be ruled out, together with cemento-ossifying fibro- 


\section{Bibliografía}

1. Ching AS, Pak MW, Kew J, Metreweli C, CT and MR Imaging appearances of an Extraosseus Calcifying Epithelial Odontogenic Tumor (Pindnorg Tumor), Am J Neuroradiol 2000;21:343-5.

2. Germanier Y, Bornstein MM, Stauffer E, Buser D, Calcifying epithelial odontogenic (Pindborg) tumor of the mandible with clear cell component treated by conservative surgery: report of a case. J Oral Maxilofaci Surg 2005;63:1377-82.

3. Belmonte-Caro R, Torres-Lagares D, Mayorga-Jiménez F, García-Perla García A, Infante-Cossio P, Gutiérrez-Pérez JL, Calcifying epithelial odontogenic tumor (Pindborg tumor). Med Oral 2002;7:309-15.

4. Patiño B, Fernández-Alba J, Garcia-Rozado A, Martin R, Lopez-Cedrún JL, Sanromán $B, C$ alcifying epithelial odontogenic (pindborg) tumor: a series of 4 distinctive cases and a review of the literature. J Oral Maxilofac Surg 2005;63:13618.

5. Maiorano E, Renne G, Tradati N, Viale G. Cytogical features of calcifying epithelial odontogenic tumor (Pindborg tumor) with abundant cementum-like material, Virchows Arch 2003;442:107-10. ma, ameloblastic fibro-odontoma and ameloblastic fibroma. If there is considerable bleeding the differential diagnosis should include central angioma of the mandible. ${ }^{3}$ If there are clear cells, the clear cell odontogenic carcinoma should also be considered together with clear cell ameloblastoma, intraosseous carcinoma, salivary gland neoplasms and aggressive osteoblastoma. ${ }^{5}$

The treatment is basically surgical and this should be tailored in each case according to the extension, location and characteristics of the patient. If conservative treatment is elected entailing enucleation, or curettage with a healthy tissue margin, together with a prolonged follow-up, the recurrence rate of $15-30 \%$ over 2-4 years should be taken into account. ${ }^{4}$ Therefore, due to its infiltrative nature, a clinical and radiological resection with a one centimeter margin of healthy tissue is preferable ( 0.5 for peripheral tumors as they are less aggressive) and a recurrence-free outcome will in this way be achieved. In cases affecting the jaw, in other words the clear cell variety, a more aggressive approach should be taken. ${ }^{5}$ As a result the best treatment method is to include 1-1.5 cm margins together with a follow-up period of $5-10$ years. ${ }^{4}$

\section{Conclusions}

Pindborg tumor is a rare benign lesion. Given its unpredictable behavior and its unspecific radiological findings, carrying out an anatomopathologic study is necessary, as is resective surgery in order to minimize the probability of recurrence. Also necessary is a postoperative follow-up of at least five years. 